\title{
MEASUREMENTS OF THE EFFECT OF HEAT SHOCKS ON SURVIVAL AND GROWTH OF NATURAL ZOOPLANKTON POPULATIONS
}

\author{
M. DONZE
}

(N.V. KEMA, Utrechtseweg 310, 6812 AR Arnhem, The Netherlands)

\section{SUMMARY}

In our research on the biological effects of thermal pollution on fresh-water plankton, natural plankton populations are enclosed in floating tanks of $2 \mathrm{~m}^{3}$ capacity, depth $2 \mathrm{~m}$. The tanks are filled with water that has or has not passed an industrial cooling circuit. In experiments lasting 14 days, plankton counts are made. From the population dynamics of individual species we try to infer the effects of heat shocks in nature.

Previously (DONZE, 1978), using temperatures up to $34^{\circ} \mathrm{C}$, a mortality around $75 \%$ was demonstrated in Cladocera, an effect that was generally compensated by regrowth in about a week. At the "Shell-Moerdijk" petrochemical plant, higher temperatures could be realized in a propene condenser. Here our work was continued during 1976 and 1977, in the Hollands Diep. The conclusions concerning zooplankton can be summarized as follows.

\begin{tabular}{|l|l|l|l|}
\hline \multirow{4}{*}{} & \multicolumn{3}{|c|}{ mortality after a maximum temperature of } \\
\cline { 2 - 4 } & $30^{\circ} \mathrm{C}$ & $34^{\circ} \mathrm{C}$ & $40^{\circ} \mathrm{C}$ \\
\cline { 2 - 4 } Cladocera & $0 \%$ & $50-80 \%$ & $100 \%$ \\
Copepoda & $0 \%$ & $0 \%$ & $95 \%$ \\
Rotatoria & $0 \%$ & $0 \%$ & $50 \%$ \\
\hline
\end{tabular}

This type of experiment appeared highly repeatable.

After incomplete killing of a species by excessive heat shock, its population developed in first approximation parallel to the blank, the survivors showing a similar growth rate as the untreated populations.

Perturbations in quantitative species composition due to excessive heat shock did not prominently change the growth rates of zooplankton species. The interaction of species did not appear in our data on the time scale used.

\section{References}

DONZE, M., 1978. Measurements of the effect of heating on survival and growth of natural plankton polulations. Verh.Internat.Verein Limnol., 20:1822-1826. 